Forthcoming at Social Problems

https://doi.org/10.1093/socpro/spaa066

\title{
Right-Wing Stewards: The Promoting Effect of Religiosity on Environmental Concern Among Political Conservatives in A Global Context
}

\author{
Peyman Hekmatpour ${ }^{1}$ \\ University of Oklahoma
}

Abstract

Email: peyman.hekmatpour@ou.edu

This article studies the relationship between individuals' religiosity, political ideology, and environmental concern, in a cross-national setting. Drawing data from multiple waves of the World Values Survey (1999-2009), the final sample of this study includes 44,391 respondents nested in 43 countries. By using a multi-level modeling technique, I find that, in general, religiosity is positively associated with respondents' environmental concerns in terms of willingness to pay for the environment, agreement with increased taxes to prevent environmental pollutions, and choosing environmental protection over economic interests. Political ideology, measured via individuals' self-placement on a left-right continuum, does not have a meaningful relationship with environmental concern in a global setting. Nevertheless, I observe an interaction effect between religiosity and political ideology. Increased religiosity, particularly among more conservative individuals, is associated with a higher probability of environmental concern. Comparatively, religiosity virtually does not affect liberals' concern for the natural environment. In other words, the gap between liberals and conservatives regarding the natural environment is more pronounced at lower levels of religiosity; as religiosity increases, the gap starts to narrow. Results suggest that religion has the potential to elevate some of the political barriers on the way towards reaching a collective environmental consciousness.

Keywords: environmental concern, religiosity, political ideology, environmental sociology, sociology of religion, cross-national sociology

\footnotetext{
${ }^{1}$ The author is grateful to editors of Social Problems, as well as to the three anonymous reviewers. Many thanks to Thomas J. Burns and Cyrus Schleifer for their insightful comments on earlier drafts of this paper. Please direct correspondence to the author at the Department of Sociology, 780 Van Vleet Oval, Kaufman Hall, Room 337A, Norman, OK 73019-2033; email: peyman.hekmatpour@ ou.edu.
} 


\section{Introduction}

We are living in a global era marked by fundamental and ever-exacerbating changes to the natural environment that are primarily caused by human activities (Steffen et al. 2015; Crutzen 2002, 2006). Previous research suggests that cultural and social institutions, through shaping humans' attitudes towards the environment, and routinizing environmental beliefs and practices, decisively influence the world of nature (Bazerman \& Hoffman 2000; Hoffman \& Ventresca 2002; Burns et al. 2018). The environmental effects of institutions such as the economy (e.g., King and Stewart 1996; Foster et al. 1999; Moore 2000; Castree 2003; Liverman 2004; Kopnina 2017), education (e.g., Chawla and Cushing 2007; Hungerford and Volk 1990; Tilbury 1995; Otto and Pensini 2017; Evans et al. 2018), and social movements (Snow and Benford 1988; Caniglia et al. 2015; Burns and LeMoyne 2001; Lee 2015; Pang and Law 2017; Brulle and Pellow 2006) are well studied and established in the environmental sociology literature.

This paper, however, focuses on religion and the polity as two of the most powerful social institutions capable of influencing the natural environment through several possible mechanisms (Burns et al. 2018). Previous studies on the relationship between religion and the environment are inconclusive. A number of researchers suggest that religion, particularly in the form of organized Abrahamic traditions (viz., Judaism, Christianity, and Islam) that advocate the domination of humans over the earth, can negatively impact the world of nature (White 1967; Hand \& Van Liere 1984; Eckberg and Blocker 1996; Greeley 1993; Schultz et al. 2000; Bulbulia et al. 2016; Peifer et al. 2016).

Comparatively, the literature suggests that the adherents of "Eastern" religions (e.g., Hinduism, Shinto, Taoism, and Buddhism) tend to care more about the natural environment, 
relative to followers of Abrahamic traditions (Sarre 1995; Bond 2016; Dwivedi 2005; Narayanan 2001; Gifford \& Nilsson 2014). Nevertheless, a significant number of scholars, by providing theoretical arguments and empirical evidence, challenge the plausibility of this thesis (Hitzhusen 2007; Hekmatpour et al. 2017; Gottlieb 2006; Rice 2006; Vitell 2009; Minton et al. 2015; Goodchild 2004). Moreover, several studies conducted in different parts of the world, contend that religious individuals, in general, tend to show higher levels of environmental concern, compared to non-religious people (Minton et al. 2015; Felix and Braunsberger 2016; Martin and Bateman 2014).

Many scholars have investigated the relationship between the polity, as a social institution, and the natural environment (e.g., Burns et al. 2018; Dunlap et al. 2001; Dunlap and McCright 2015). At the macro-level, previous studies suggest that governments' membership in international environmental organizations, passing enforceable pro-environmental laws, politicizing environmental issues in the public debate, pro-globalization policies, and foreign direct investment (FDI), are among political factors influencing the natural environment (Bager et al. 2015; Hironaka 2002; Frank et al. 2000; McCright and Dunlap 2011a; Hirsch 2001; Baek and Koo 2009).

Also, different political ideologies, primarily through steering the public debate and collective actions of citizens, tend to impact the natural environment (Bäckstrand 2003; Frank et al. 2007). The literature suggests that liberalism, as a political ideology, relative to conservativism, is associated with a higher level of environmental concern (e.g., Peifer et al. 2016; Mostafa 2016; Dalton 2015; Clements et al. 2014; Wardekker et al. 2009; Wapner 1996; Guth et al. 1995; Samdahl and Robertson 1989; Shaiko 1987). Comparatively, conservatives are hypothesized to show less concern for the natural environment (Antonio and Brulle 2011; 
Dunlap et al. 2001; McCright and Dunlap 2000; Hamilton and Saito 2015, Newman et al. 2016; Choma et al. 2016).

In this paper, drawing on data from the World Values Survey (1999-2009) and by using a multi-level analytical technique, I examine the effects of religiosity and political ideology on individuals' environmental concern in a global setting. A small number of studies have examined the relationship between different aspects of religiosity (e.g., religious beliefs, attending, and importance), political orientations, and environmental concern in a cross-national setting (see Mostafa 2016). I use an aggregated index to measure respondents' religiosity, which is more comparable across different cultures. I find that religiosity, regardless of the context, promotes environmental concern among individuals. In other words, more religious individuals, net of their religious tradition, tend to have a higher probability of showing concern for the environment. Also, I find that individuals' political ideology (liberal vs. conservative) does not have a significant relationship with environmental concern in a cross-national setting.

Nevertheless, I contribute to this line of research by observing an interaction effect between respondents' religiosity and political ideology. Increased religiosity, particularly among conservatives, is associated with a higher probability of environmental concern. Comparatively, religiosity virtually does not affect liberals' concern for the natural environment. In other words, the gap in the environmental concern of liberals and conservatives is more pronounced at lower levels of religiosity, and it narrows as religiosity increases. I propose two different theoretical mechanisms that can explain this observation. Finally, I discuss my findings in terms of policy implications. 


\section{Background and Theoretical Framework}

Historically, religions have shaped our relationship with the non-human world in two distinct ways. Through religious teachings, we have framed the natural world in human terms, for the most part, to satisfy our materialistic needs. On the other hand, religion is considered to be the "voice of nature to humanity," reminding us of our inescapable connectedness to the natural environment (Gottlieb 2003). The former has been the dominant idea in the environmental research following the publication of Lynn White's (1967) classic article, "The Historical Roots of Our Ecologic Crisis." He argues that our present environmental problems are rooted in a number of religious ideas, such as the "domination of man over the earth," and "the specialness of humankind." These notions are shared by major Abrahamic traditions: Judaism, Christianity, and Islam (Hekmatpour et al. 2017). Alternatively, non-Abrahamic traditions, including Eastern religions such as Hinduism and Buddhism, and the indigenous faiths of native Americans are believed to be more environmentally friendly (Hitzhusen 2007; Bond 2016).

Lynn White's argument has received mixed support from empirical studies (e.g., Hand \& Van Liere 1984; Eckberg and Blocker 1996; Greeley 1993). For instance, Schultz and associates (2000), in a cross-national study, found that "a literal belief in the Bible leads to a general concern for oneself and other people but not necessarily to a concern for plants and animals." (Schultz et al. 2000: 588). A more recent study in New Zealand found "a positive link between frequency of scripture reading and religious fundamentalism, and between religious fundamentalism and lower pro-environmental intentions.” (Bulbulia et al. 2016: 278). Similarly, another recent study in the United States suggests that "belief in an involved God and biblical literalism are negatively related" to individuals' consideration of the environmental impacts of their decisions when they purchase goods and services (Peifer et al. 2016: 661). 
Nevertheless, White's argument also has been widely criticized in the literature. Two crucial factors are highlighted by critics (Hitzhusen 2007). First, the mastery of humankind over the earth cannot be primarily attributed to religious ideas, and they can be caused by other institutional or cultural factors such as political ideology. Second, individuals' attitudes and behaviors, particularly in the religious sphere, are not necessarily congruous (see Chaves 2010). The Evangelical Environmental Network's campaign to reduce personal fuel consumption, "What Would Jesus Drive" in 2002, can serve as an example of incongruity between attitudes and behaviors regarding the natural environment (Gottlieb 2006).

A number of scholars have discussed the possibility of an alternative interpretation of the scripture in Abrahamic traditions that can help develop an environmentally friendly ethos (White 1967; Hitzhusen 2007; Burns 2016; Hekmatpour et al. 2017). Pope Francis (2015), in his Encyclical, Laudato Si, introduces Saint Francis of Assisi as a Christian role model for environmental conservation. Moreover, Sufism, the mystical branch of Islam, for the most part, due to its emphasis on selflessness and unity of existence, can be a potential resource for encouraging environmental stewardship in the Islamic culture (Hekmatpour et al. 2017).

Several researchers have suggested that Eastern traditions, such as Hinduism, Buddhism, and Taoism, along with indigenous American faiths, for the most part, due to their emphasis on a holistic, and in some cases animistic relationships between humans and the natural world, are more environmentally friendly (Bond 2016; Dwivedi 2005; Narayanan 2001). Bron Taylor (2001a) explores the influence of Eastern traditions, indigenous faiths, nature-oriented religions such as neo-paganism, and other practices associated with 'New Age' spirituality on the formation of the philosophy of modern environmental movements such as deep ecology and radical environmentalism. While the proponents of these earth-based spiritualities primarily 
focus on personal experiences in nature, they have borrowed several practices and ideals from Eastern and indigenous religions (Taylor 2001b).

Western religious traditions (i.e., Judaism, Christianity, and Islam), on the other hand, share the belief in an almighty God who has created humans, and has given them superiority over His other creations, the natural world. Nevertheless, followers of Eastern traditions and indigenous American faiths, in general, follow a pantheistic view of the world - that God, and other supernatural powers, are immanent in the world of nature (James 2003 [1902]). Therefore, scholars have theorized the adherents of Eastern religions to show higher levels of environmental concern, relative to followers of Western traditions (Sarre 1995).

Empirical studies in this line of research are scarce (see Gifford \& Nilsson 2014), yet, recent findings suggest that in a cross-national setting, highly religious Buddhists are more likely to engage in sustainable behaviors, such as purchasing green products, recycling, and consuming organic foods, compared to both Christians and atheists (Minton et al. 2015). Nevertheless, significant trends within Western religions have started to promote environmental conservation among their adherents, discussing the possibility of new eco-theologies (Minton et al. 2015; Hitzhusen 2007; Goodchild 2004). For example, in 2004, the National Association of Evangelicals (NAE) published a position statement advocating efforts to prevent environmental degradations, including the issue of global warming (Djupe and Gwiasda 2010).

Religion is a significant source of morality from which individuals can draw, among other things, their environmental ethics (Rice 2006; Vitell 2009). Therefore, an alternate view suggests that religiosity, regardless of the context, can be conducive to the process of environmental protection. Gottlieb $(2006,2003)$ contends the possibility of environmentalism in all religious traditions. Religious environmentalism is capable of motivating numerous 
individuals, offering richer vocabularies compared to secular environmentalism, and providing a "comprehensive vision of humans and their place in the world." (Szerszynski 2008: 89; Gottlieb 2006).

Furthermore, religious environmentalism is hypothesized to be able to change people's minds about the natural environment through emphasizing the sacred interdependence of humans and nature (Gottlieb 2006). A growing body of empirical studies supports the claim that in general, religious individuals, ceteris paribus, are more likely to adopt eco-centric and more environmentally friendly attitudes (Minton et al. 2015; Felix and Braunsberger 2016; Martin and Bateman 2014). However, a recent qualitative study maintains that while religion, in general, can motivate environmentally friendly practices, the environmental concern becomes constrained when believers feel that environmental commitment might undermine their religious beliefs (Vaidyanathan et al. 2018).

The case of the environmental justice movement provides an insightful example of the significance of religion and religious organizations in the shaping of attitudes, and guiding proenvironmental practices. In 1982, a low-income African American community in North Carolina, primarily organized by local religious organizations, protested a toxic waste dump and started the national environmental justice movement in the United States (McGurty 2007; Sze and London 2008). Moreover, according to several observers, the publication of the United Church of Christ's report on racial differences in exposure to hazardous toxic waste in 1987 marks the beginning of the environmental justice debate in both public policy and academia (Chavis and Lee 1987; United Church of Christ 1987; Sze and London 2008; Mohai, Pellow, and Roberts 2009). By connecting religious and faith-based organizations with student groups, communitybased organizations, and scientific associations, the environmental justice movement has been 
able to effectively impact legislation processes at the state and federal levels in favor of the proenvironmental policies (Sandler and Pezzullo 2007). Religion has helped the environmental justice movement by reframing environmental problems as moral issues (Binder 1999). Outside of the United States, particularly in South America, the "church of liberation theology," mainly through linking environmental stewardship to human rights and equality, has motivated many to join movements struggling for social justice (Carruthers 2008).

Research contends that various aspects of religion contribute to pro-environmental behavior in different ways. For instance, Dilmaghani (2018) shows that only religious attendance, among other dimensions of religiosity, is positively associated with environmental volunteerism. Also, as several other scholars have suggested, religion does not act solely in the shaping of people's perceptions, attitudes, and activities regarding the world of nature. The effect of religion is moderated by individuals' values, knowledge, and political ideology (Bhuian et al. 2018; Burns et al. 2018; Burns 2009; Gifford and Nilsson 2014; Hitzhusen 2007; Shaiko 1987; Woodrum and Wolkomir 1997; Wolkomir et al. 1997; Guth et al. 1995).

The significance of religion as a relevant factor in the shaping of environmental attitudes and behavior might be questionable in regard to the process of secularization in all areas of the world (Hekmatpour 2020). Secularization thesis is a family of distinct theories predicting a range of different outcomes for religion in the face of modernization, including the ultimate disappearance of religion (Marx 1978 [1844]; Freud 1953 [1923]; Lenski 1961; Berger 1969), a decline in the authority of religious leaders and organizations (Weber 1948 [1919]; Chaves 1994), privatization and specialization of religion (Luckman 1967, 1990; Luhmann 1982), and normalization of non-religious beliefs, thoughts, and practices (Taylor 2007). By highlighting the resurgence of religion in the public and political spheres of many countries in the late 20th 
century, critics have argued for the "desecularization" of the world (Berger 1999) and the possibility of entering a "post-secular" era (Habermas 2009; Taylor 2014). Several commentators believe that "desecularization" has resurrected the significance of religion in global politics (Paipais 2020; Mavelli and Petito 2014)

Moreover, there is evidence that the historical legacies of religion continue to shape secular politics regardless of whether fewer people believe in religious teachings or not (Schmitt 2005). For instance, through a comprehensive historical study, Stoll (2017) traces the roots of contemporary American environmentalism in Reformed Protestant beliefs of Calvinists and New England Congregationalists. Recently, a number of scholars have called for more insights into the relationship between religion and the environment (Wilkins 2020; Ives and Kidwell 2019). This said, one must not overstate the current role of religion in the shaping of individuals' environmental attitudes. Religions might not be a vital factor, but can play an essential role in "[the] articulations of individual positionalities, the production of various theoretical and corporeal constructions of nature, the legitimation of interpersonal governance through environmental forms, and [serve] as catalysts for resistance movements.” (Wilkins 2020: 15) Moreover, religion might be a crucial element in the shaping of social values, which can translate into pro-environmental attitudes and practices (Ives and Kidwell 2019).

Previous research also suggests that different political ideologies, primarily through steering the public debate and collective actions of citizens, tend to impact the natural environment (Bäckstrand 2003; Frank et al. 2007). Political conservativism, defined as an ideology that values notions such as "free market" and "small government," have a decisive, and for the most part, negative effect on the natural environment. (Antonio and Brulle 2011; Dunlap et al. 2001; McCright and Dunlap 2000; Hamilton and Saito 2015, Newman et al. 2016; Choma 
et al. 2016). Policies designed to protect the natural environment, in many cases, require local, federal, and global governments to interfere with the "free market" by regulating businesses and corporations (Krieg 1998; Jenkins and Eckert 2000). Government's interference in the market challenges fundamental values of conservativism, and thus drives many conservatives towards adapting less environmentally friendly attitudes and practices (Jenkins and Eckert 2000; Dunlap and Gale 1974).

Research also suggests that the conservative media is deeply influenced by a number of elites who provide financial support to turn the public opinion against environmentalism, mainly via propagating doubts about, and denial of the existence of anthropogenic environmental problems, particularly climate change (McCright and Dunlap 2003, Jacques et al. 2008, Guber 2013; Hamilton 2011, Coffey and Joseph 2012). Conservative elites tend to question the scientific basis of climate change, claiming that attempts to counteract global warming (e.g., reducing fossil fuel consumption and greenhouse gas emissions) negatively impact society (Jacques et al. 2008; McCright and Dunlap 2000). This anti-environmentalist mass propaganda has a crucial impact on the adoption of pro-environmental attitudes and behaviors among conservatives (McCright et al. 2014).

Conservatives share a tendency towards preserving the status quo and supporting the existing political system (Jost et al. 2004). The "systems justifying tendencies," to some extent, can explain why conservatives, in general, tend to show lower levels of environmental concern, particularly regarding specific issues such as the climate change (Feygina et al. 2010; McCright and Dunlap 2011a). There is evidence that conservatives are less likely to embrace proenvironmental attitudes because environmental conservation, in many cases, requires fundamental changes in people's familiar ways of living (Feygina et al. 2010). Furthermore, the 
"systems justifying tendencies" provide conservatives with reduced levels of anxiety, feelings of guilt, dissonance, discomfort, and uncertainty, particularly regarding controversial issues such as anthropogenic environmental degradation (Jost et al. 2004; Jost and Hunyady 2002).

Several studies emphasize the centrality of pro-environmental attitudes and behaviors in liberal political ideologies (e.g., Peifer et al. 2016; Mostafa 2016; Dalton 2015; Clements et al. 2014; Wardekker et al. 2009; Wapner 1996; Guth et al. 1995; Samdahl and Robertson 1989; Shaiko 1987). Therefore, even though environmental degradation affects both liberals and conservatives to the same extent, since conservatives often otherize liberals as outsiders based on a variety of other issues (e.g., taxation, immigration, abortion, etc.), they tend to show less environmental concern in order to distance themselves from liberals and their central values, including environmentalism (Hochschild 2016; Burns and LeMoyne 2001).

Previous cross-national studies find a positive relationship between some aspects of religiosity, including the frequency of prayer and the importance of God, and concern for global warming (Mostafa 2016). However, religion does not shape individuals' environmental attitudes and actions all by itself. For instance, Brian McCammack (2007) argues that, in the United States, "while all evangelicals are theologically conservative, they are not necessarily all politically conservative" (pp. 646). There is a divide within the evangelical movement regarding environmental issues. While liberal evangelicals are inclined to broaden their political agenda to include pro-environmental policies, conservative evangelicals are still reluctant to do so, mainly because they do not want to compromise on their other core beliefs, such as their position on abortion, in a coalition with political liberals (McCammack 2007). Therefore, in this paper, I attempt to explain the difference in environmental concern, through focusing on individuals' choosing of the environment over economic interests, and by interacting religiosity and political 
ideology. My goal is to provide a more rigorous understanding of how religious and political values interact to shape individuals' environmental attitudes.

\section{Data and Method}

My analyses use data from the World Values Survey (WVS) (Inglehart et al. 2014). ${ }^{1}$ This database includes measures of attitudes toward the natural environment across a large number of countries and years, including both Western and non-Western societies. Measures of attitudes toward the natural environment are not included in all waves of the survey. Thus, I use two waves $\left(4^{\text {th }}\right.$ and $\left.5^{\text {th }}\right)$ of the survey covering a time period of 10 years (from 1999 to 2009). The final sample includes 44,391 observations from 43 countries. $^{2}$ Appendix A lists countries represented in the sample and numbers of observations contributed by each country. I also use supplementary databases, such as the Penn World Table ${ }^{3}$ (Feenstra et al. 2015), Polity IV Project $^{4}$ (Marshall et al. 2014), World Development Indicators ${ }^{5}$ (World Bank 2015), and Carbon Dioxide Information Analysis Center ${ }^{6}$ (CDIAC 2011), for level-two (country) control variables.

\section{Dependent Variable}

Analyses presented in this paper include three dependent variables. I construct the first outcome variable, willingness to pay (WTP) for the environment, as a binary variable by recoding the original measure in the database. The WVS asks respondents to indicate their attitude toward the statement "I would give part of my income for the environment" on a fourpoint scale ("Strongly Agree," "Agree," "Disagree," and "Strongly Disagree"). To distinguish

\footnotetext{
${ }^{1}$ www.worldvaluessurvey.org

${ }^{2}$ This number of countries in the sample is large enough to avoid problems related to small numbers of level-two observations in multilevel analyses (Stegmueller 2013).

${ }^{3}$ www.rug.nl/ggdc/productivity/pwt/

${ }^{4}$ www.systemicpeace.org/polity/polity4.htm

${ }^{5}$ www.data.worldbank.org/products/wdi

${ }^{6}$ Www.cdiac.ess-dive.lbl.gov/
} 
individuals who show some degree of willingness to pay for the environment from those who do not, I code this information into a binary variable that differentiates respondents answering either "Strongly Agree" or "Agree," versus all others. In the final sample, 65.35\% of respondents show a WTP for the environment.

The second outcome variable is individuals' agreement with an increase in taxes (AIT) assuming that the extra revenue will be used to prevent environmental pollution. In the survey, respondents were asked to indicate their agreement, or disagreement with "[An] increase in taxes if extra money [is] used to prevent environmental pollution," on a four-point scale. I code this information into a binary variable in the same way I did for WTP. In the final sample, 55.75\% of respondents show some degree of AIT to prevent environmental pollution.

Finally, the third outcome variable, choosing environmental protection over economic interests (CEP), is a combination of the first two. I construct a binary variable differentiating respondents who agree with both WTP and AIT versus those who do not. In the final sample, $48.72 \%$ of respondents show agreement with both WTP and AIT while others either agree with only one of these outcomes, or with none.

\section{Key Independent Variables}

This study aims to investigate the effects of two key independent variables, Religiosity and Political ideology, on the outcomes of interest. The Religiosity variable is a continuous index constructed from three items: religious importance, self-identification as a religious person, and 
frequency of religious attendance. In constructing the religiosity index, I follow Welzel (2013) who justified the validity and reliability of this index in a global context. ${ }^{1}$

By focusing on three different aspects of religiosity (i.e., religious salience, identity, and behavior), this measure is intended to capture the level of individuals' religiousness in all countries. There might be some concerns regarding the appropriateness of using such a multidimensional index in all social settings under study in this research. Several researchers have tried to test the suitability of using a multidimensional religiosity index, both crossculturally and within different religious traditions (e.g., De Jong, Faulkner, and Warland 1976; Smith, Weigert, and Thomas 1979; Dy-Liacco et al. 2009; Hu 2017; Lemos et al. 2019). For instance, Dy-Liacco et al. (2009) examined the relevance of western religiosity constructs to be used for non-western settings (in their case, the Philippines) and found strong evidence supporting the suitability of a religiosity index based on common western concepts such as belief, practice, and salience.

Moreover, a recent study using confirmatory factor analysis (CFA) on data from the International Social Survey Programme (ISSP) concludes that a religiosity index built from items such as religious importance and belief in God, believing in the afterlife, and religious involvement is a reliable measure in terms of factorial invariance, not only for Christians but also for religiously unaffiliated respondents in 26 countries (Lemos et al. 2019). Another study presents results of CFA models maintaining that the three Bs (belonging, behaving, and believing) can also be used to construct a religiosity index for Buddhists (Hu 2017). Therefore,

\footnotetext{
${ }^{1}$ For more information and a detailed discussion of Welzel's indices refer to the online appendix of Freedom Rising: Human Empowerment and the Quest for Emancipation available at: www.cambridge.org/c1/download_file/473755/
} 
in this research, I use available measures in the World Values Survey to develop a religiosity index.

WVS asks respondents to indicate, on a four-point scale, how important they believe religion is in their life ( $1=$ Very Important, $2=$ Rather Important, $3=$ Not very Important, and $4=$ Not at all Important). I reverse code this item $(0=$ Not at all Important, $1=$ Not very Important, $2=$ Rather Important, and 3=Very Important) and divide the values by 3 to have a range of 0 to 1 .

The survey asks respondents whether they identify themselves as a religious person or not, giving them three options to choose from: 1) A religious person, 2) Not a religious person, and 3) A convinced atheist. I code this information into a binary variable where respondents identifying as a religious person are coded 1 and others 0 .

Respondents' frequency of religious attending is measured on a seven-point scale (1=More than once a week, $2=$ Once a week, $3=$ Once a month, $4=$ Only on special holidays, $5=$ Once a year, $6=$ Less often, and $7=$ Never practically never). $I$ reverse code this item to change the direction toward attending more frequently $(0=$ Never practically never to $6=$ More than once a week) and divide the values by 6 to have a range of 0 to 1 . I sum the recoded items to create the religiosity index with a Cronbach's alpha of $0.73 .{ }^{1}$ The religiosity index ranges from 0 (non-

\footnotetext{
${ }^{1}$ To further justify the use of this religiosity index, I did an Item Response Theory (IRT) test. IRT is a statistical approach based on the principles of Confirmatory Factor Analysis (CFA) which is specifically developed to evaluate the quality of measures (Kean and Reilly 2014; Hekmatpour and Burns 2019). IRT assesses the quality of a measure through estimating the correlation between the predicted latent factor that loads on the observed variable, and the index created by the researcher (Harvey and Hammer 1999). Here, this correlation is very strong $(\mathrm{r}=0.974)$ and statistically significant $(p<0.001)$, showing the validity of the religiosity index developed in this study. Moreover, results from separate CFA models on the three items across different religious traditions show evidence supporting factor invariance, and the latent religiosity measure specified in these CFA models for all traditions is highly correlated with the aggregate religiosity index used in this paper. These results are available upon request.
} 
religious) to 1 (highly religious). This measure has a mean of 0.65 and a standard deviation of 0.31 in the sample.

In this study, another key independent variable is Political Ideology (PI). The WVS asks respondents to indicate where they would place their political views on a scale of 1 (Left) to 10 (Right). Since there is no reasonable cutoff point to categorize this scale, neither based on theory nor the conventional wisdom, I decide treat this variable as a continuous measure. ${ }^{1}$ This variable is widely used as a measure of respondents' political ideology in cross-national research on attitudes towards the natural environment (see Kvaløy et al. 2012; Torgler and García-Valiñas 2007; Neumayer 2004; McCright et al. 2016).

\section{Individual-Level Control Variables}

I control the analyses for the impacts of a set of individual-level variables, including income, gender, age, education, marital status, number of children, employment status, social class, life satisfaction, and religious tradition. Respondents' Age is a continuous measure ranging from 15 to 99 . I control for respondents' Gender with a binary indicator for males. The WVS asks respondents to identify the level of household Income, compared to other households within their country, on a scale of 1 (lowest income group in the country) to 10 (highest income group).

\footnotetext{
${ }^{1}$ I also tested models that categorized this measure by taking the middle of the scale $(\mathrm{PI}=5)$ as a cutoff point and coded the information into three categories: Left $(\mathrm{PI}<5)$, Middle $(\mathrm{PI}=5)$, and Right $(\mathrm{PI}>5)$. No considerable difference was observed in the results due to this transformation. I also tried dummy indicators for extreme levels, Left $(\mathrm{PI}=1)$ and Right $(\mathrm{PI}=10)$, both separately and in conjunction and did not find any significant difference in my results. Models using categorical transformations of political ideology are available upon request.
} 
In the sample, this variable has a mean of 4.80 with a standard deviation of 2.35 . I treat this variable as a continuous measure. ${ }^{1}$

The WVS measures the highest Educational level attained by respondents on a nine-point scale. I recode this information into a variable with three categories: "Elementary or less Education" (including original categories: No formal education, Incomplete primary school, and Complete primary school), "Secondary Education" (including original categories: Incomplete secondary school: technical/vocational type, Complete secondary school: technical/vocational type, Incomplete secondary school: university-preparatory type, Complete secondary school: university-preparatory type) and "Higher Education" (including original categories: Some university-level education without a degree, University-level education with a degree). By taking the first category as the reference group, I will be able to see whether receiving secondary level or higher education, compared to having elementary or no formal education, can influence individuals' attitudes toward the natural environment.

The survey asks respondents to indicate their current Marital Status choosing from a number of available options (1=Married, 2=Living together, 3=Divorced, 4=Separated, 5=Widowed, 6=Single/Never married). Being married means being more financially responsible and since in this study I am investigating what makes individuals choose environmental protection over personal economic interests, it is reasonable to collapse these categories into a binary variable differentiating individuals who are currently married (1) from others (0). Here, the rationale is that married individuals, due to their financial responsibilities, are less likely to choose environmental protection over economic interests. In the analyses, I control for the

\footnotetext{
${ }^{1}$ I also tested a model that categorizes this measure by collapsing it into 5 income quintiles for each country. No qualitative differences were observed in my results due to this transformation. Models using income quintiles are available upon request.
} 
Number of Children, a continuous measure ranges from 0 to 8 , with the same rationale as for the marital status.

Respondents' Employment Status is measured by a categorical variable (1=Full-time, 1=Part-time, $3=$ Self-Employed, 4=Retired, 5=Housewife, $6=$ Student, 7=Unemployed, $8=$ Other). Defining an employed person to be an individual who is economically active, I collapse these categories into two: Employed (Full-time, Part-time, Self-employed), and Unemployed (other categories). Employed respondents, due to having relatively more stable levels of income relative to unemployed individuals, can be hypothesized to be more likely to choose environmental protection over economic interests.

I include individuals' Social Class as a control variable in the analyses. I hypothesize that upper-class individuals, due to their stable position in the economy, are more likely to choose environmental protection, compared to lower-class respondents who are struggling to meet their basic needs. The WVS asks respondents to indicate their belonging to one of the social classes listed ( $1=$ Upper class, $2=$ Upper middle class, $3=$ Lower middle class, $4=$ Working class, $5=$ Lower class). The upper-class category roughly covers $1.5 \%$ of respondents in the sample. Therefore, I merge these individuals into the "Upper middle class" category, making a new category called "Upper middle class and above."

I include individuals' Life Satisfaction in the analyses due to the importance of this variable in predicting pro-environmental attitudes shown in the literature (Felix et al. 2018). The WVS asks respondents to indicate, on a scale of 1 (Completely dissatisfied) to 10 (Completely satisfied), how satisfied they are with their life. I treat this measure as a continuous variable.

For all cross-cultural studies investigating the effect of religiosity, it is important to consider the religious context. Thus, I control for individuals' Religious Traditions. The WVS 
does not record religious traditions in a pre-standardized way. Instead, the survey provides respondents with an open-ended question asking them to identify their religious denomination. In the sample of this study, there are 63 different denominations that respondents identify with. I collapse this information into seven general categories (i.e., Protestant, Orthodox, Catholic, Buddhist, Muslim, Other, and Non-Religious). Appendix A lists these denominations and how they are categorized into the general groups.

\section{Country-Level Control Variables}

I control the analyses for the impacts of four country-level (level-two) variables: GDP per capita, Unemployment rate, $\mathrm{CO}_{2}$ emissions per capita, and Democracy. GDP per capita is an indicator of a country's level of affluence. According to the theory of post-materialism (Inglehart 1997; Norris and Inglehart 2004), individuals who are living in more affluent countries where their basic material needs are met, will be more likely to embrace post-material ideas and attitudes such as environmental concern. I draw data on countries' GDP per capita from the Penn World Table version 9.0 (Feenstra et al. 2015). In this database, GDP per capita is measured as the real gross domestic product at chained purchasing power parity (PPP) rates adjusted for 2011 United States dollars. I use the natural logarithm transformation of GDP per capita to adjust for the skewness observed in the distribution of this variable.

The Unemployment rate is measured as the percent share of the total active labor force who are not currently employed. This variable is drawn from the World Development Indicators (World Bank 2015) database. A high unemployment rate is a sign of economic recession. Thus, the rationale to control for this variable is that individuals living in countries where the economy suffers from a recession are less likely to choose environmental protection over their personal economic interests. 
There is a significant number of studies discovering a positive association between different aspects of Democracy (e.g., more freedom and less corruption) and environmental protection (e.g., Congleton 1996; Barrett and Graddy 2000; Farzin and Bond 2006; Pellegrini and Gerlagh 2006). Therefore, I decide control for countries' levels of democracy. I draw a democracy index from the Polity IV Project database (Marshall et al. 2014). This index ranges from -7 (complete autocracy) to 10 (full democracy). I treat this variable as a continuous measure indicating the level of democracy in countries.

The rationale to include $\mathrm{CO}_{2}$ emissions per capita in the analyses is that it is reasonable to hypothesize people who are living in countries where the natural environment is already degraded, to be more likely to choose environmental protection over personal economic interests. Yet, individuals who are not directly suffering from environmental problems have fewer incentives to choose the environment over the economy. $\mathrm{CO}_{2}$ emissions per capita are measured as cumulative carbon dioxide emissions (from burning fossil fuels and manufacturing activities) in tons per capita. I draw this measure from the Carbon Dioxide Information Analysis Center (CDIAC 2011). Table 1 includes the descriptive statistics for the independent variables. ${ }^{1}$

\section{[TABLE 1 ABOUT HERE]}

\section{Analytical Strategy}

Since the outcome variables are binary, I use a logistic regression model to predict individuals' attitudes toward environmental protection. However, since the data are nested within countries, I use a multi-level mixed-effect form of the logistic regression that takes into account

\footnotetext{
${ }^{1}$ I tested for possible multicollinearity of independent variables at both individual and country levels. All variance inflation factors (VIF) were found to be below 4, the conventional critical point, and the average of VIFs is 1.98 . The maximum VIF is for the GDP per capita variable and equals to 3.44. Thus, multicollinearity is not a concern in my analyses.
} 
the possible heterogeneity imposed by unmeasured characteristics of each country. ${ }^{1}$ This model can be specified as:

$$
\begin{aligned}
& \ln \left(\frac{\operatorname{Pr}\left(Y_{i}=1\right)}{1-\operatorname{Pr}\left(Y_{i}=1\right)}\right)=\beta_{0, j}+\beta_{1,0} X_{i, j}+e_{i, j} \\
& \beta_{0, j}=\gamma_{0,0}+\gamma_{0,1} W_{j}+e_{0, j}
\end{aligned}
$$

In equation $1, Y_{i}$ is the value of the outcome variable for the individual $i$ while $X_{i, j}$ is a vector of individual-level independent variables with the accompanying $\beta_{1,0}$ vector of regression coefficients. $\beta_{0, j}$ is a vector of country-specified random intercepts. As we can learn from equation 2, country-specified random intercepts are a function of country-level independent variables $\left(W_{j}\right)$ and the average of all country-specified intercepts $\left(\gamma_{00}\right) .^{2}$ Two separate error terms, $e_{i, j}$ and $e_{0, j}$, account for the possible heterogeneity caused by the nested data structure.

For each outcome variable, I use the statistical package STATA 15 to estimate two mixed-effect logistic models, one with the main effects of religiosity and political ideology and one additional model including the interaction effect of these two variables. Through these models, I investigate whether individuals' religiosity affects their attitudes towards environmental protection, and whether this effect is moderated by political ideology. I report the AIC (Akaike information criterion) and BIC (Bayesian information criterion) as two comparative

\footnotetext{
${ }^{1}$ The interclass correlation coefficient (ICC) shows that $17.4 \%$ of the variance in the residuals of WTP is at country-level. This coefficient is $11.9 \%$ for AIT and $12.5 \%$ for CEP. This provides further evidence that a multi-level modeling technique is preferable because a simple logistic approach might yield biased results due to the unmeasured country-specific characteristics. ${ }^{2}$ This model uses random intercepts and fixed slopes. The regression coefficients of independent variables are forced to be fixed across countries. In other words, this model assumes that for each independent variable, the direction of the effect is the same across all countries. This assumption can cause a number of controversies and concerns, especially regarding the main effects of interests in this study (i.e., religiosity, and political ideology). To acknowledge these concerns, I conducted several sensitivity analyses, allowing both religiosity and political ideology to have random slopes across countries. No considerable difference was observed in results. Models with random slopes are available upon request.
} 
model fit statistics. I do acknowledge that the results of these models are based on observational data, thus, include all the shortcomings of non-experimental research designs. Therefore, I make no causal claim based on my findings.

\section{Results}

To answer the primary question of this study - how religiosity and political ideology affect individuals' attitudes towards the environment - I estimate three multi-level mixed-effects logistic regression models in Table 2. The first model in this table shows the odds ratios of willingness to pay for the environment (WTP), the second model shows the odds ratios of agreement with increased taxes (AIT) to prevent environmental pollution, and the third model shows the odds ratios of choosing environmental protection (CEP) over economic interests. In these models, I have conditioned the effect of religiosity and political ideology on level-1 and level-2 control variables.

\section{[TABLE 2 ABOUT HERE]}

As we can see, religiosity has a positive (odds ratios greater than one) and statistically significant relationship with environmental attitudes across all three models. However, given the large sample size, p-values are not so informative here. Therefore, from now on, I primarily focus on the magnitudes of effects. According to the first model, one standard deviation increase in individuals' religiosity increases the odds of WTP by a factor of 1.172 , net of the effect of other variables. In other words, this model predicts that, in a global context, one standard deviation increase in religiosity, on average, increases the predicted probability of WTP by 3.1 percent. Put it another way, this model predicts that $62.36 \%$ of individuals with average religiosity scores $(\mathrm{z}$-score $=0$ ) will show a willingness to pay for the environment. Comparatively, holding other variables constant, the predicted probability of WTP is $68.56 \%$ for respondents with religiosity scores two standard deviations above the average. 
According to the second model, $53.57 \%$ of respondents with average religiosity scores (zscore $=0$ ) show AIT to prevent environmental pollution. However, the predicted probability of AIT is $58.17 \%$ for individuals with religiosity scores two standard deviations above the average. Moreover, the third model predicts that $47.09 \%$ of individuals with the average level of religiosity $(\mathrm{z}$-score $=0)$ will choose environmental protection over economic interests while the predicted probability of CEP is $52.69 \%$ for respondents with religiosity scores two standard deviation above the average.

These results suggest that an increased religiosity promotes pro-environmental attitudes. ${ }^{1}$ Models control for individuals' religious traditions. In other words, the analyses suggest that more religious individuals, net of their religious tradition ${ }^{2}$, have higher probabilities of showing environmentally friendly attitudes. However, the magnitude of this effect, roughly a $3 \%$ increase in predicted probability, is relatively small, and given the large sample size, the significance of the observed effect of religiosity can be questionable.

As we can see in Table 2, the other predictor of interest, political ideology, in its continuous form with a direction towards more conservative political ideologies, does not have a relationship with outcome variables. This suggests that although the natural environment is

\footnotetext{
${ }^{1}$ In order to make sure that this general finding - that increased religiosity positively impacts individuals' probability of showing environmental concern - does not change from one tradition to another, I estimated additional models where I interacted religiosity by religious tradition. The results suggest that this positive relationship can be observed within all religious traditions included in this study. Models are available upon request.

${ }^{2}$ There might be a concern regarding the categorization of religious traditions in broad groups such as Protestant. As I mentioned in the literature review, previous studies find differences between liberal (Mainline) and conservative (Evangelical) protestants in environmental attitudes and practice. However, this effect is more pronounced in the United States. In order to see whether these differences are observable in a global sample, I estimated additional models where I broke down the Protestant group into two sub-groups of Mainline and Evangelical. Results do not change according to this alternative categorization of religious traditions. Models are available upon request.
} 
highly politicized in public debates of many countries, especially the United States (McCright and Dunlap 2011b; McCright et al. 2014), on a global scale, individuals' political positions on the Left-Right spectrum is not a determinant of their pro-environmental attitudes. Yet, as I discussed above, there might be a potential interaction effect between religiosity and political ideology in predicting attitudes towards the environment.

\section{[TABLE 3 ABOUT HERE]}

In Table 3, I introduce the interaction effect of religiosity by political ideology to previous models. Regarding the recent concerns raised by a number of scholars about the use of p-values for regression models of binary outcomes with interaction effects (Mustillo, Lizardo, and M. McVeigh 2018), I only focus on the direction and magnitudes of the interaction terms and main effects, as well as predicted probabilities. Controlling for the effects of level-1 and level-2 covariates, the interaction term of religiosity by political ideology, across all three models, has a positive coefficient. The interaction terms show the mutually reinforcing effect of religiosity and political ideology. The direction of the political ideology variable is towards more politically conservative ideologies ( $1=$ Left, 10=Right). Thus, the positive interaction term captures the effect of increased religiosity among more politically conservative individuals. This interaction effect is visualized in Figure 1 that shows predicted probabilities of outcome variables by religiosity across political ideology. Non-overlapping confidence intervals suggest that across all dependent variables, there is a significant gap between liberals and conservatives in terms of environmental concern when religiosity is at its lowest level. This gap narrows and eventually closes (overlapping confidence intervals) as religiosity increases.

[FIGURE 1 ABOUT HERE] 
From Figure 1, we can see that among individuals with the lowest level of religiosity, $68.99 \%$ of those who identify with "Left" political ideologies $(\mathrm{PI}=1)$ show a WTP for the environment. This predicted probability for those who identify with "Right" political ideologies $(\mathrm{PI}=10)$ is only $51.19 \%$. However, among individuals with the average level of religiosity (zscore $=0$ ), the predicted probability of WTP for the environment increases to $65.86 \%$ for respondents with "Right" political ideologies while it virtually does not change for those identified with "Left" political ideologies. Therefore, one standard deviation increase in religiosity increases the predicted probability of WTP for the environment by $6.27 \%$ among conservatives.

We observe a similar pattern for the second outcome variable, AIT to prevent environmental pollution. One standard deviation increase in religiosity increases conservatives' predicted probability of AIT by 5.58\%. Moreover, according to the third model in Table 3, one standard deviation increase in religiosity increases the predicted probability of CEP by $6.08 \%$ among respondents who identify with conservative or "Right" political ideologies.

The interaction effect of religiosity by political ideology, illustrated in Figure 1 and examined in Table 3, shows that increased levels of religiosity promote environmental concern, particularly among more politically conservative individuals. The overall effect of one standard deviation increase in religiosity, when it is not interacted by political ideology (in Table 2), is approximately a $3 \%$ increase in predicted probability. However, the interaction term shows that the promoting effect of religiosity is higher (around 6\% increase in predicted probability) among the conservatives.

This observation supports the hypothesis that religiosity, to some extent, can mitigate the political divide over the natural environment. As we saw, the gap between "Right" and "Left" is 
more pronounced at lower levels of religiosity, and narrows as religiosity increases. It appears that religion can provide means to overcome some of the political barriers on the way towards reaching a collective environmental consciousness. The analyses show that more religious conservatives have a higher probability of adopting environmentally friendly attitudes, while religiosity virtually does not affect liberals' typically greater concern for the natural environment. Thus, religion can be conducive to the process of depoliticizing the natural environment in the public debate.

\section{Discussion and Conclusion}

In this research, I found that religiosity, on a global scale and regardless of its context, promotes environmental concern in terms of choosing the environment over economic interest. Moreover, the most novel contribution of this paper is the observed interaction effect of religiosity by political ideology on environmental concern. I found that the promoting effect of religiosity on environmental concern is more pronounced among conservatives. Peifer and associates (2016) observe a similar pattern in American society and attribute it to the cognitive process of the "systems justifying tendencies." (Peifer et al. 2016; Jost et al. 2004) They contend that the belief in an active God who constantly intervenes the world lessens the fear of change, and "perhaps conservatives with a strong belief in an involved God are less worried about change, alleviating one conservative impediment to environmental consumption." (Peifer et al. 2016: 684). Given the fact that the majority of the sample of this study consists of individuals who follow Abrahamic traditions, particularly Christianity and Islam (see Table 1), this 
explanation can be plausible. However, it is important to consider a more cultural explanation for this observation.

Environmentalism is a central concept in liberal political ideologies. Conservatives "otherize" liberals as outsiders based on key issues in their own ideology, such as taxation, immigration, and abortion, and tend to show less environmental concern in order to distance themselves from environmentalism as one of the central values of liberals (Hochschild 2016; Burns and LeMoyne 2001). In other words, conservatives' position regarding the environmental issues is more of a reaction to liberals', rather than a central value in their own ideology.

For religious individuals, religion is the most central motif - or as Burns and LeMoyne (2001) call it, the "prioritizing summary symbol" - and other values, including political ideology, are peripheral. Highly religious conservatives tend less to otherize liberals, or at least religious liberals with whom they share a number of values, and thus are more open to embracing pro-environmental attitudes. Therefore, contradictions and antagonisms, such as the liberal versus conservative debate on anthropogenic environmental problems, can be resolved by increased religiosity.

Today, the natural environment appears to be highly politicized in the public debates of several countries, particularly the United States, to the extent that a number of observers consider particular environmental problems, such as the climate change, as "tribal" issues, dividing the population into two opposing camps (Cloud 2016). A significant number of individuals tend to associate "environmentalism" more with liberal political ideologies (Hutchings 2005; Faulkner 1993). Thus, we observe a vast political divide between liberals and conservatives over the natural environment. 
Feinberg and Willer (2013) point out that liberals and conservatives view the natural environment, not only from politically distinct viewpoints but also from different moral perspectives. They argue that the contemporary environmental discourse, which is dominated by liberal ideologies, is built on the moral values related to caring for, and protection of others, particularly the disadvantaged and harmed people. However, a reframed pro-environmental rhetoric based on the moral value of purity, or the concern about the sacredness of the world, can attract a larger number of conservatives to the cause of environmental protection (Feinberg and Willer 2013).

Therefore, the incorporation of religious vocabularies into the discourse of the environmental movements, along with using the teachings of the world religions regarding the natural environment, can help policymakers and social activists encourage a more significant number of people to become involved in environmental conservation. A political alliance between environmental movements and religious institutions, for the most part through depoliticizing the natural environment, can eventually lead to a collective environmental consciousness.

Finally, religion continues to be a powerful social force capable of influencing virtually every aspect of human life. Social scientists and religious scholars commonly tend to isolate the effects of religion by merely controlling for other factors in stochastic models. However, my findings suggest the impact of religion on people's attitudes and behaviors, particularly regarding sensitive issues such as anthropogenic environmental degradation, is channeled through and moderated by other variables such as political ideology. Moreover, the results emphasize the importance of the cross-cultural examination of the effects of religion. Given the fact that we are living in an era of globalization (Ritzer 2015), it is of vital importance for social scientists in 
general, and sociologists in particular, to expand their research beyond the local and national boundaries. 


\section{References}

Antonio, Robert J., and Robert J. Brulle. 2011. "The unbearable lightness of politics: Climate change denial and political polarization.” The Sociological Quarterly 52(2): 195-202.

Bäckstrand, Karin. 2003. "Civic science for sustainability: reframing the role of experts, policymakers and citizens in environmental governance." Global Environmental Politics 3(4): 24-41.

Baek, Jungho, and Won W. Koo. 2009. "A dynamic approach to the FDI-environment nexus: the case of China and India." East Asian Economic Review 13(2): 78-160.

Bager, Alex, Carlos E. Borghi, and Helio Secco. 2015. "The influence of economics, politics, and environment on road ecology in South America." in Van der Ree, Rodney, Daniel J. Smith, and Clara Grilo (eds.), Handbook of road ecology. Chichester, West Sussex: Wiley Blackwell.

Barrett, Scott, and Kathryn Graddy. 2000. "Freedom, growth, and the environment." Environment and development economics 5(4): 433-456.

Bazerman, Max H., and Andrew John Hoffman. 2000. "Sources of environmentally destructive behavior: Individual, organizational and institutional perspectives." Research in Organizational Behavior 21: 39-79.

Berger, Peter L. 1969. The Sacred Canopy. New York: Doubleday.

Berger, Peter L., ed. 1999. The Desecularization of the World: Resurgent Religion and World Politics. Washington, D.C. : W.B. Eerdmans Pub. Co.

Bhuian, Shahid Nakib, Sujeet Kumar Sharma, Irfan Butt, and Zafar U. Ahmed. 2018.

"Antecedents and pro-environmental consumer behavior (PECB): the moderating role of religiosity." Journal of Consumer Marketing 35(3): 287-299.

Binder, Lisa A. 1999. "Religion, Race, and Rights: A Rhetorical Overview of Environmental Justice Disputes," Wisconsin Environmental Law Journal 6(1): 1-64.

Bond, Erik. 2016. "Native Voices, The Indigenous View of Environmentalism: Tribe, Nature, and Kinship." in Caniglia, Beth S., Thomas J. Burns, Rachel M. Gurney, and Erik L. Bond (eds.), Rise of Environmental Consciousness: Voices in pursuit of a sustainable planet. San Diego, CA: Cognella.

Brulle, Robert J, David N. Pellow. "Environmental justice: Human health and environmental inequalities." Annu. Rev. Public Health 27:103-124.

Bulbulia, Joseph, Geoffrey Troughton, Lara M. Greaves, Taciano L. Milfont, and Chris G. Sibley. 2016. "To burn or to save? The opposing functions of reading scripture on environmental intentions.” Religion, Brain \& Behavior 6(4): 278-289.

Burns, Thomas J. 1999. "Rhetoric as a framework for analyzing cultural constraint and change." Current Perspectives in Social Theory 19: 165-186.

Burns, Thomas J. 2009. "Culture and the Natural Environment." in Alpina Begossi and Priscila F. Lopes (eds.), Current Trends in Human Ecology. Newcastle upon Tyne, U.K.: Cambridge Scholars Press.

Burns, Thomas J. 2016. "Reconsidering Scripture in Late Industrial Society: Religious Traditions and the Natural Environment." in Caniglia, Beth S., Thomas J. Burns, Rachel M. Gurney, and Erik L. Bond (eds.), Rise of Environmental Consciousness: Voices in pursuit of a sustainable planet. San Diego, CA: Cognella.

Burns, Thomas J., and Terri LeMoyne. 2001. "How environmental movements can be more effective: Prioritizing environmental themes in political discourse." Human Ecology Review 8(1): 26-38. 
Burns, Thomas J., Peyman Hekmatpour, and Kristen C. Speer. 2018. "Human Interaction with the Natural Environment: The POETICAS Model as a Framework for Understanding and Praxis in Late Modernity." International Journal of environment and climate change 8(3): 234-268.

Caniglia, Beth Schaefer, Robert J. Brulle, and Andrew Szasz. 2015. "Civil society, social movements, and climate change." in Dunlap, Riley and Robert J. Brulle (eds.), Climate Change and Society: Sociological Perspectives. New York: Oxford University Press.

Carruthers, David V. 2008. Environmental Justice in Latin America: Problems, Promise, and Practice (Urban and Industrial Environments). Cambridge, MA.: The MIT Press.

Castree, Noel. 2003 “Commodifying what nature?” Progress in Human Geography 27(3):273297.

CDIAC, Navigate, C. D. I. A. C. Staff, C. O. Fossil-Fuel, Emissions Trace Gas Emissions, AmeriFlux Network, and C. O. Ocean. 2011. "Carbon Dioxide Information Analysis Center." Available at: www.cdiac.ess-dive.lbl.gov/

Chaves, Mark. 1994. "Secularization as Declining Religious Authority." Social Forces 72(3):749-74.

Chaves, Mark. 2010. "SSSR presidential address rain dances in the dry season: Overcoming the religious congruence fallacy." Journal for the Scientific Study of Religion 49(1): 1-14.

Chavis, Benjamin Jr., and Charles Lee. 1987. United Church of Christ Commission on Racial Justice, Toxic Wastes and Race in the United States: A National Report on the Racial and Socio-Economic Characteristics of Communities with Hazardous Waste Sites. New York, NY: United Church of Christ.

Chawla, Louise., and Debra Flanders Cushing. 2007. "Education for strategic environmental behavior." Environmental Education Research 13(4):437-452.

Choma, Becky L., Yaniv Hanoch, and Shannon Currie. 2016. "Attitudes toward hydraulic fracturing: The opposing forces of political conservatism and basic knowledge about fracking." Global Environmental Change 38: 108-117.

Clements, John M., Aaron M. McCright, and Chenyang Xiao. 2014. "Green Christians? An empirical examination of environmental concern within the US general public." Organization \& Environment 27(1): 85-102.

Cloud, Doug. 2016. "Communicating Climate Change to Religious and Conservative Audiences." Reflections 16: 57-73.

Coffey, Daniel J., and Patricia Hallam Joseph. 2013. "A polarized environment: The effect of partisanship and ideological values on individual recycling and conservation behavior." American Behavioral Scientist 57(1): 116-139.

Congleton, Roger D. 1992. "Political institutions and pollution control." The review of economics and statistics : 412-421.

Crutzen, Paul J. 2002. "Geology of mankind.” Nature 415(6867): 23.

Crutzen, Paul J. 2006. "The "anthropocene.” In Ehlers, Eckart and Thomas Krafft. Earth System Science in the Anthropocene: Emerging Issues and Problems. Berlin: Springer.

Dalton, Russell J. 2015. "Waxing or waning? The changing patterns of environmental activism." Environmental Politics 24(4): 530-552.

Dilmaghani, Maryam. 2018. "Which is greener: secularity or religiosity? Environmental philanthropy along religiosity spectrum." Environmental Economics and Policy Studies 20(2): 477-502. 
Djupe, Paul A., and Gregory W. Gwiasda. 2010. "Evangelizing the environment: Decision process effects in political persuasion." Journal for the Scientific Study of Religion 49(1): 73-86.

Dunlap, Riley E., and Richard P. Gale. 1974. "Party membership and environmental politics: A legislative roll-call analysis." Social Science Quarterly 55 (3): 670-690.

Dunlap, Riley E., Chenyang Xiao, and Aaron M. McCright. 2001. "Politics and environment in America: Partisan and ideological cleavages in public support for environmentalism.” Environmental politics 10(4): 23-48.

Dwivedi, O. P. 2005. "Satyagraha for conservation: A Hindu view.” in Pojman, Louis P. (ed) Environmental Ethics: Readings in Theory and Application. Belmont, CA: Wadsworth/Thomson.

Eckberg, Douglas Lee, and T. Jean Blocker. 1996. "Christianity, environmentalism, and the theoretical problem of fundamentalism." Journal for the Scientific Study of Religion 35(4): 343-355.

Evans, Gary W, Siegmar Otto, Florian G. Kaiser. 2018. "Childhood origins of young adult environmental behavior." Psychological Science 29(5):679-687.

Farzin, Y. Hossein, and Craig A. Bond. 2006. "Democracy and environmental quality." Journal of Development Economics 81(1): 213-235.

Faulkner, Robert K. 1993. "The United States: Liberals, Conservatives, and the Challenge of Liberation." Political Studies 41(1): 107-132.

Feenstra, Robert C., Robert Inklaar and Marcel P. Timmer .2015. "The Next Generation of the Penn World Table" American Economic Review 105(10): 3150-3182.

Felix, Reto, Chris Hinsch, Philipp A. Rauschnabel, and Bodo B. Schlegelmilch. 2018. "Religiousness and environmental concern: A multilevel and multi-country analysis of the role of life satisfaction and indulgence.” Journal of Business Research 91: 304-312.

Foster, John Bellamy, Brett Clark, and Richard York. 2011. The ecological rift: capitalism's war on the Earth. New York: Monthly Review Press.

Francis, Pope. 2015. Laudato si: On care for our common home. Vatican City: Libreria Editrice Vaticana.

Frank, David John, Ann Hironaka, and Evan Schofer. 2000. "The nation-state and the natural environment over the twentieth century." American Sociological Review 65(1): 96-116.

Freud, Sigmund. 1953 [1923]. "Future of an Illusion." in Complete Psychological Works of Sigmund Freud: The Standard Edition edited by J. Strachey, A. Freud, A. Strachey and A. Tyson. London: Hogarth Press.

Feinberg, Matthew, and Robb Willer. 2013. "The moral roots of environmental attitudes." Psychological Science 24(1): 56-62.

Feygina, Irina, John T. Jost, and Rachel E. Goldsmith. 2010. "System justification, the denial of global warming, and the possibility of "system-sanctioned change"." Personality and social psychology bulletin 36(3): 326-338.

Greeley, Andrew. 1993. "Religion and attitudes toward the environment." Journal for the Scientific Study of Religion 32(1): 19-28.

Gifford, Robert, and Andreas Nilsson. 2014. "Personal and social factors that influence proenvironmental concern and behaviour: A review." International Journal of Psychology 49(3): 141-157.

Gottlieb, Roger S. 2003. This sacred earth: Religion, nature, environment. New York: Routledge. 
Gottlieb, Roger S. 2006. A Greener Faith: Religious Environmentalism and Our Planet's Future. Oxford: Oxford University Press.

Guber, Deborah Lynn. 2013. "A cooling climate for change? Party polarization and the politics of global warming." American Behavioral Scientist 57(1): 93-115.

Guth, James L., John C. Green, Lyman A. Kellstedt, and Corwin E. Smidt. 1995. "Faith and the environment: Religious beliefs and attitudes on environmental policy." American Journal of Political Science 39(2): 364-382.

Habermas, Jürgen. 2009 "What is Meant by "Post-Secular Society"? A Discussion on Islam in Europe" in Habermas, Jürgen. (ed.). Europe: The Faltering Project. Cambridge: Polity Press.

Hamilton, Lawrence C. 2011. "Education, politics and opinions about climate change evidence for interaction effects." Climatic Change 104(2): 231-242.

Hamilton, Lawrence C., and Kei Saito. 2015. "A four-party view of US environmental concern." Environmental Politics 24(2): 212-227.

Hand, Carl M., and Kent D. Van Liere. 1984. "Religion, mastery-over-nature, and environmental concern." Social Forces 63(2): 555-570.

Harvey, Robert J., and Allen L. Hammer. 1999. "Item response theory." The Counseling Psychologist 27(3): 353-383.

Haynes, Jeff. 2014. Religion in global politics. New York: Routledge.

Hekmatpour, Peyman, Thomas J. Burns, and Tom W. Boyd. 2017. "Is Islam Pro-or AntiEnvironmental? Interpretations and Implications.” Journal of Asian Research 1(1): 92110.

Hekmatpour, Peyman, and Thomas J. Burns. 2019. "Perception of Western governments' hostility to Islam among European Muslims before and after ISIS: the important roles of residential segregation and education.” The British Journal of Sociology 70 (5): 21332165.

Hekmatpour, Peyman. 2020. "Inequality and Religiosity in a Global Context: Different Secularization Paths for Developed and Developing Nations." International Journal of Sociology (Online First, doi: 10.1080/00207659.2020.1771013).

Hironaka, Ann. 2002. "The globalization of environmental protection: The case of environmental impact assessment." International Journal of Comparative Sociology 43(1): 65-78.

Hirsch, Philip. 2001. "Globalisation, regionalisation and local voices: The Asian Development Bank and rescaled politics of environment in the Mekong region." Singapore Journal of Tropical Geography 22(3): 237-251.

Hitzhusen, Gregory E. 2007. "Judeo-Christian theology and the environment: moving beyond scepticism to new sources for environmental education in the United States." Environmental Education Research 13(1): 55-74.

Hochschild, Arlie R. 2016. Strangers in their own land: Anger and mourning on the American right. New York: The New Press.

Hoffman, Andrew J. and Marc J. Ventresca. 2002. Organizations, Policy and the Natural Environment: Institutional and Strategic Perspectives. Stanford, CA: Stanford University Press.

Hungerford, Harold R, Trudi L. Volk. 1990. "Changing learner behavior through environmental education." The Journal of Environmental Education 21(3):8-21.

Hutchings, Kevin. 2005. "Don't Call Me a Tree Hugger!: Sticks, Stones, and Stereotypes in Ecocriticism.” Interdisciplinary Literary Studies 7(1): 5-26. 
Inglehart, Ronald. 1997. Modernization and Postmodernization: Cultural, Economic, and Political Change in 43 Societies. Princeton: Princeton University Press.

Inglehart, R., C. Haerpfer, A. Moreno, C. Welzel, K. Kizilova, J. Diez-Medrano, M. Lagos, P. Norris, E. Ponarin and B. Puranen et al. (eds.). 2014. World Values Survey: All RoundsCountry-Pooled Datafile Version. Madrid: JD Systems Institute.

Ives, Christopher D., and Jeremy Kidwell. 2019. "Religion and social values for sustainability." Sustainability Science 14(5): 1355-1362.

Jacques, Peter J., Riley E. Dunlap, and Mark Freeman. 2008. "The organisation of denial: Conservative think tanks and environmental scepticism." Environmental politics 17(3): 349-385.

James, William. 2003 [1902]. The varieties of religious experience: A study in human nature. New York: Routledge.

Jenkins, J. Craig, and Craig M. Eckert. 2000. "The right turn in economic policy: Business elites and the new conservative economics." Sociological Forum 15(2): 307-338.

Jenkins, Willis, and Christopher Key Chapple. 2011. "Religion and environment." Annual Review of Environment and Resources 36: 441-463.

Jost, John, and Orsolya Hunyady. 2003. "The psychology of system justification and the palliative function of ideology." European review of social psychology 13(1): 111-153.

Jost, John T., Mahzarin R. Banaji, and Brian A. Nosek. 2004. "A decade of system justification theory: Accumulated evidence of conscious and unconscious bolstering of the status quo." Political psychology 25(6): 881-919.

Kean, Jacob, and Jamie Reilly. 2014. "Item response theory." in Handbook for Clinical Research: Design, Statistics and Implementation. New York, NY: Demos Medical Publishing.

King, David A, and William P. Stewart. 1996. "Ecotourism and commodification: protecting people and places." Biodiversity \& Conservation 5(3):293-305.

Kopnina, Helen. 2017. "Commodification of natural resources and forest ecosystem services: Examining implications for forest protection." Environmental Conservation 44(1):24-33

Krieg, Eric J. 1998. "The two faces of toxic waste: trends in the spread of environmental hazards." Sociological Forum 13(1): 3-20.

Kvaløy, Berit, Henning Finseraas, and Ola Listhaug. 2012. "The publics' concern for global warming: A cross-national study of 47 countries." Journal of Peace Research 49(1): 11 22.

Lee, Francis LF. 2015. "Internet, citizen selfmobilisation, and social movement organisations in environmental collective action campaigns: Two Hong Kong cases.” Environmental Politics 24(2):308- 325.

Lenski, Gerhard E. 1961. The Religious Factor: A Sociological Study of Religion's Impact on Politics, Economics, and Family Life. Garden City, NY: Doubleday.

Liverman, Diana. 2004. "Who governs, at what scale and at what price? Geography, environmental governance, and the commodification of nature." Annals of the Association of American Geographers 94(4):734-738.

Luckmann, Thomas. 1967. The Invisible Religion. New York, NY.: Macmillan.

Luckmann, Thomas. 1990. "Shrinking Transcendence, Expanding Religion?". Sociological Analysis 51(2):127-38.

Luhmann, Niklas. 1982. The Differentiation of Society. New York, NY.: Columbia University Press. 
Marshall, Monty G., Ted Robert Gurr, and Keith Jaggers. 2014. Polity IV project: Political regime characteristics and transitions, 1800-2013. Vienna, VA: Center for Systemic Peace.

Martin, William C., and Connie R. Bateman. 2014. "Consumer religious commitment's influence on ecocentric attitudes and behavior." Journal of Business Research 67(2): 5-11.

Marx, Kark. 1978 [1844]. "Contribution to the Critique of Hegel's Philosophy of Right: Introduction." in The Marx-Engels Reader, edited by R. C. Turker. New York, NY.: Norton.

Mavelli, Luca, and Fabio Petito. Towards a Postsecular International Politics: New Forms of Community, Identity, and Power. New York: Palgrave Macmillan.

McCammack, Brian. 2007. "Hot damned America: Evangelicalism and the climate change policy debate." American Quarterly 59(3): 645-668.

McGurty, Eileen Maura. 2007. Transforming Environmentalism: Warren County, PCBS, and the Origins of Environmental Justice. New Brunswick, NJ: Rutgers University Press.

McCright, Aaron M., and Riley E. Dunlap. 2000. "Challenging global warming as a social problem: An analysis of the conservative movement's counter-claims." Social problems 47(4): 499-522.

McCright, Aaron M., and Riley E. Dunlap. 2003. "Defeating Kyoto: The conservative movement's impact on US climate change policy." Social problems 50(3): 348-373.

McCright, Aaron M., and Riley E. Dunlap. 2011a. "Cool dudes: The denial of climate change among conservative white males in the United States." Global environmental change 21(4): 1163-1172.

McCright, Aaron M., and Riley E. Dunlap. 2011b. "The politicization of climate change and polarization in the American public's views of global warming, 2001-2010." The Sociological Quarterly 52(2): 155-194.

McCright, Aaron M., Riley E. Dunlap, and Sandra T. Marquart-Pyatt. 2016. "Political ideology and views about climate change in the European Union." Environmental Politics 25(2): 338-358.

McCright, Aaron M., Chenyang Xiao, and Riley E. Dunlap. 2014. "Political polarization on support for government spending on environmental protection in the USA, 1974-2012." Social Science Research 48: 251-260.

Minton, Elizabeth A., Lynn R. Kahle, and Chung-Hyun Kim. 2015. "Religion and motives for sustainable behaviors: A cross-cultural comparison and contrast." Journal of Business Research 68(9): 1937-1944.

Mohai, Paul, David Pellow, and J. Timmons Roberts. 2009. "Environmental justice." Annual review of environment and resources 34: 405-430.

Moore, Jason W. 2000. "Environmental crises and the metabolic rift in world-historical perspective.” Organization \& Environment 13(2):123-157.

Mostafa, Mohamed M. 2016. "Post-materialism, religiosity, political orientation, locus of control and concern for global warming: a multilevel analysis across 40 nations." Social Indicators Research 128(3): 1273-1298.

Mustillo, Sarah A., Omar A. Lizardo, and Rory M. McVeigh. 2018. "Editors' Comment: A Few Guidelines for Quantitative Submissions.” American Sociological Review 83(6): 128183.

Narayanan, Vasudha. 2001. "Water, wood, and wisdom: Ecological perspectives from the Hindu traditions." Daedalus 130(4): 179-206. 
Neumayer, Eric. 2004. "The environment, left-wing political orientation and ecological economics." Ecological economics 51(3-4): 167-175.

Newman, Brian, James L. Guth, William Cole, Chris Doran, and Edward J. Larson. 2016. "Religion and environmental politics in the US house of representatives." Environmental Politics 25(2): 289-314.

Norris, Pippa, and Ronald Inglehart. 2004. Sacred and Secular: Religion and Politics Worldwide. New York: Cambridge University Press.

Otto, Siegmar., Pamela Pensini. 2017. "Nature based environmental education of children: Environmental knowledge and connectedness to nature, together, are related to ecological behaviour." Global Environmental Change 47:88-94.

Paipais, Vassilios. 2020. Theology and World Politics: Metaphysics, Genealogies, Political Theologies. New York: Palgrave Macmillan.

Pang, Natalie, Pei Wen Law. 2017. "Retweeting\# world environment day: A study of content features and visual rhetoric in an environmental movement." Computers in Human Behavior 69:54-61

Peifer, Jared L., Simranjit Khalsa, and Elaine Howard Ecklund. 2016. "Political conservatism, religion, and environmental consumption in the United States." Environmental Politics 25(4): 661-689.

Pellegrini, Lorenzo, and Reyer Gerlagh. 2006. "Corruption, democracy, and environmental policy: an empirical contribution to the debate." The Journal of Environment \& Development 15(3): 332-354.

Rice, Gillian. 2006. "Pro-environmental behavior in Egypt: Is there a role for Islamic environmental ethics?." Journal of business ethics 65(4): 373-390.

Ritzer, George. 2015. Globalization: a Basic Text. Chichester, West Sussex: John Wiley \& Sons, Inc.

Samdahl, Diane M., and Robert Robertson. 1989. "Social determinants of environmental concern: Specification and test of the model." Environment and behavior 21(1): 57-81.

Sandler, Phaedra C., and Ronald D. Pezzullo, (eds.). 2007. Environmental justice and environmentalism: The social justice challenge to the environmental movement. Cambridge, MA.: MIT press.

Sarre, Philip. 1995. "Towards global environmental values: Lessons from western and eastern experience." Environmental Values 4(2): 115-127.

Schmitt, Carl. 2005. Political theology: Four chapters on the concept of sovereignty. Chicago, IL.: University of Chicago Press.

Schultz, P. Wesley, Lynnette Zelezny, and Nancy J. Dalrymple. 2000. "A multinational perspective on the relation between Judeo-Christian religious beliefs and attitudes of environmental concern." Environment and Behavior 32(4): 576-591.

Shaiko, Ronald G. 1987. "Religion, politics, and environmental concern: A powerful mix of passions." Social Science Quarterly 68(2): 244-262.

Snow, David A, Robert D. Benford. Ideology, frame resonance, and participant mobilization. International Social Movement Research. 1988;1(1):197-217

Steffen, Will, Wendy Broadgate, Lisa Deutsch, Owen Gaffney, and Cornelia Ludwig. 2015. "The trajectory of the Anthropocene: the great acceleration." The Anthropocene Review 2(1): 81-98. 
Stegmueller, Daniel. 2013. "How many countries for multilevel modeling? A comparison of frequentist and Bayesian approaches.” American Journal of Political Science 57(3): 748761.

Stoll, Mark. 2017. Inherit the Holy Mountain: Religion and the Rise of American Environmentalism. Oxford: Oxford University Press.

Sze, Julie, and Jonathan K. London. 2008. "Environmental justice at the crossroads." Sociology Compass 2(4): 1331-1354.

Szerszynski, Bronislaw. 2008. "A Greener Faith: Religious Environmentalism and Our Planet's Future by Roger Gottlieb.” Book Review. Organization \& Environment 21(1): 89-91.

Taylor, Bron. 2001a. "Earth and nature-based spirituality (part I): From deep ecology to radical environmentalism." Religion 31(2): 175-193.

Taylor, Bron. 2001b. "Earth and nature-based spirituality (Part II): From earth first! And bioregionalism to scientific paganism and the new age." Religion 31(3): 225-245.

Taylor, Charles. 2007. A Secular Age. Cambridge, MA.: Harvard university press.

Taylor, Charles. 2014. Dilemmas and Connections: Selected Essays. Cambridge MA.: Harvard University Press.

Tilbury, Daniella. 1995. "Environmental education for sustainability: Defining the new focus of environmental education in the 1990s." Environmental Education Research 1(2):195212.

Torgler, Benno, and Maria A. Garcia-Valiñas. 2007. "The determinants of individuals' attitudes towards preventing environmental damage." Ecological economics 63(2-3): 536-552.

United Church of Christ 1987. Toxic Wastes and Race in the United States. New York, NY: Commission for Racial Justice.

Vaidyanathan, Brandon, Simranjit Khalsa, and Elaine Howard Ecklund. 2018. "Naturally Ambivalent: Religion's Role in Shaping Environmental Action.” Sociology of Religion 79(4): 472-494.

Vitell, Scott J. 2009. "The role of religiosity in business and consumer ethics: A review of the literature." Journal of Business Ethics 90(2): 155-167.

Wapner, Paul Kevin. 1996. Environmental activism and world civic politics. Albany: Suny Press.

Wardekker, J. Arjan, Arthur C. Petersen, and Jeroen P. van Der Sluijs. 2009. "Ethics and public perception of climate change: Exploring the Christian voices in the US public debate." Global Environmental Change 19(4): 512-521.

Weber, Max. 1948 [1919]. "Religious Rejections of the World and Their Directions." in From Max Weber: Essays in Sociology, edited by H. H. Gerth and C. W. Mills. New York, NY.: Oxford University Press.

Welzel, Christian. 2013. Freedom Rising: Human Empowerment and the Quest for Emancipation. New York: Cambridge University Press.

White, Lynn. 1967. “The Historical Roots of Our Ecologic Crisis.” Science 155(3767): 12031207.

Wilkins, Dominic. 2020. "Where Is Religion in Political Ecology?” Progress in Human Geography (Online First). doi:10.1177/0309132520901772.

Woodrum, Eric, and Michelle J. Wolkomir. 1997. "Religious effects on environmentalism." Sociological Spectrum: Mid-South Sociological Association 17(2): 223-234.

Wolkomir, Michelle, Michael Futreal, Eric Woodrum, and Thomas Hoban. 1997. "Substantive religious belief and environmentalism." Social Science Quarterly 78(1): 96-108.

World Bank. 2019. World development indicators. Washington, D.C. :The World Bank. Available at: www.data.worldbank.org/products/wdi 


\begin{tabular}{|c|c|c|c|}
\hline Variables & Description & $\begin{array}{c}\text { Mean or } \\
\%\end{array}$ & S.D. \\
\hline \multicolumn{4}{|l|}{ Level-1 (Individual) Variables } \\
\hline Religiosity.................... & $\begin{array}{l}\text { Min }=0 \text { (Completely Secular), Max }=1 \text { (Completely } \\
\text { Religious) }\end{array}$ & 0.65 & 0.31 \\
\hline Political Ideology .................... & $\begin{array}{l}\text { Relgious) } \\
\text { Respondents' self-positioning on a political scale of } 1 \\
\text { (Left) to } 10 \text { (Right) }\end{array}$ & 5.66 & 2.37 \\
\hline Income.. & Respondents' self-reported income on a scale of 1 to 10 & 4.80 & 2.35 \\
\hline Age............ & $\operatorname{Min}=15, \operatorname{Max}=99$ & 42.53 & 16.27 \\
\hline 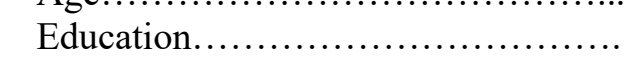 & Respondents' highest educational level attained & & \\
\hline 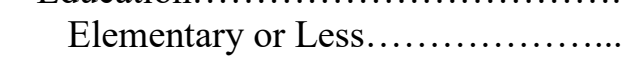 & $\begin{array}{l}\text { Including "No formal education", "Incomplete", and } \\
\text { "Completed" elementary level }\end{array}$ & $25.4 \%$ & - \\
\hline Secondary Education (High School) & $\begin{array}{l}\text { Including "Incomplete" and Completed" high school, } \\
\text { technical school, or pre-university levels }\end{array}$ & $50.0 \%$ & - \\
\hline Higher Education (College). & $\begin{array}{l}\text { Including "Incomplete" and "Completed" college or } \\
\text { university level }\end{array}$ & $24.6 \%$ & - \\
\hline Married................ & Respondents' current marital status & $56.7 \%$ & - \\
\hline Number of Children.. & $\operatorname{Min}=0, \operatorname{Max}=8$ & 1.95 & 1.78 \\
\hline Employed.............. & $\begin{array}{l}\text { Including "Full time", "Part time", "Self-employed", } \\
\text { and "Student" categories }\end{array}$ & $54.0 \%$ & - \\
\hline Gender (Male) & Male $=1$, Female $=0$ & $49.3 \%$ & - \\
\hline Social Class........... & Respondents' self-reported social class & & \\
\hline Lower Class.............................. & & $15.5 \%$ & - \\
\hline Working Class........................ & & $28.2 \%$ & \\
\hline 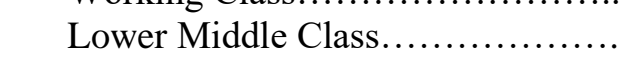 & & $35.2 \%$ & - \\
\hline Upper Middle Class and Above....... & & $21.1 \%$ & - \\
\hline Life Satisfaction.......................... & $\begin{array}{l}\text { Respondents' self-reported life satisfaction on a scale of } \\
1 \text { to } 10\end{array}$ & 6.82 & 2.31 \\
\hline Religious Tradition.. & $\begin{array}{l}\text { Respondents' self-declaration of belonging to different } \\
\text { religious denominations collapsed into the following } \\
\text { religious traditions }\end{array}$ & & \\
\hline Protestant ....... & & $18.0 \%$ & - \\
\hline 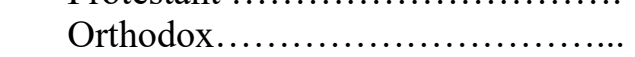 & & $10.0 \%$ & - \\
\hline Catholic............................... & & $28.7 \%$ & - \\
\hline Buddhist.......................... & & $5.2 \%$ & - \\
\hline Muslim $\ldots \ldots \ldots \ldots \ldots \ldots \ldots \ldots \ldots \ldots \ldots$ & & $17.2 \%$ & - \\
\hline Other................................. & & $5.8 \%$ & - \\
\hline No Religious Belonging .............. & & $15.1 \%$ & - \\
\hline \multicolumn{4}{|l|}{ Level-2 (Country) Variables } \\
\hline GDP per capita (Logged)... & $\begin{array}{l}\text { Real gross domestic product at chained purchasing } \\
\text { power parity }(\mathrm{PPP}) \text { rates adjusted for } 2011 \text { US } \$ \text {. Min = } \\
0.170, \text { Max }=4.056\end{array}$ & 2.49 & 1.00 \\
\hline Unemployment Rate.................... & $\begin{array}{l}\text { Percent share of the total labor force. } \operatorname{Min}=1.18 \text {, } \\
\operatorname{Max}=30.52\end{array}$ & 9.37 & 6.62 \\
\hline $\mathrm{CO}_{2}$ emissions per capita............... & $\begin{array}{l}\text { Cumulative carbon dioxide emissions (from burning } \\
\text { fossil fuels and manufacturing activities) measured per } \\
\text { capita. Min=0.51 (tons), Max }=1048.90 \text { (tons) }\end{array}$ & 249.43 & 267.00 \\
\hline Democracy..... & $\begin{array}{l}\text { Polity IV measure of Democracy, Min = }-7 \text { (Absolute } \\
\text { autocracy), Max= } 10 \text { (Full democracy) }\end{array}$ & 7.01 & 4.60 \\
\hline
\end{tabular}

Number of Observations $=44,391$

Number of Countries $=43$

Data sources:

- $\quad$ Individual Level: World Value Survey longitudinal dataset (1999 - 2009)

- Country Level: Penn World Table 9.0 - 2015; Polity IV Project - 2015; World Development Indicators - 2015. Carbon Dioxide Information Analysis Center (CDIAC) - 2011 
Dependent Variable

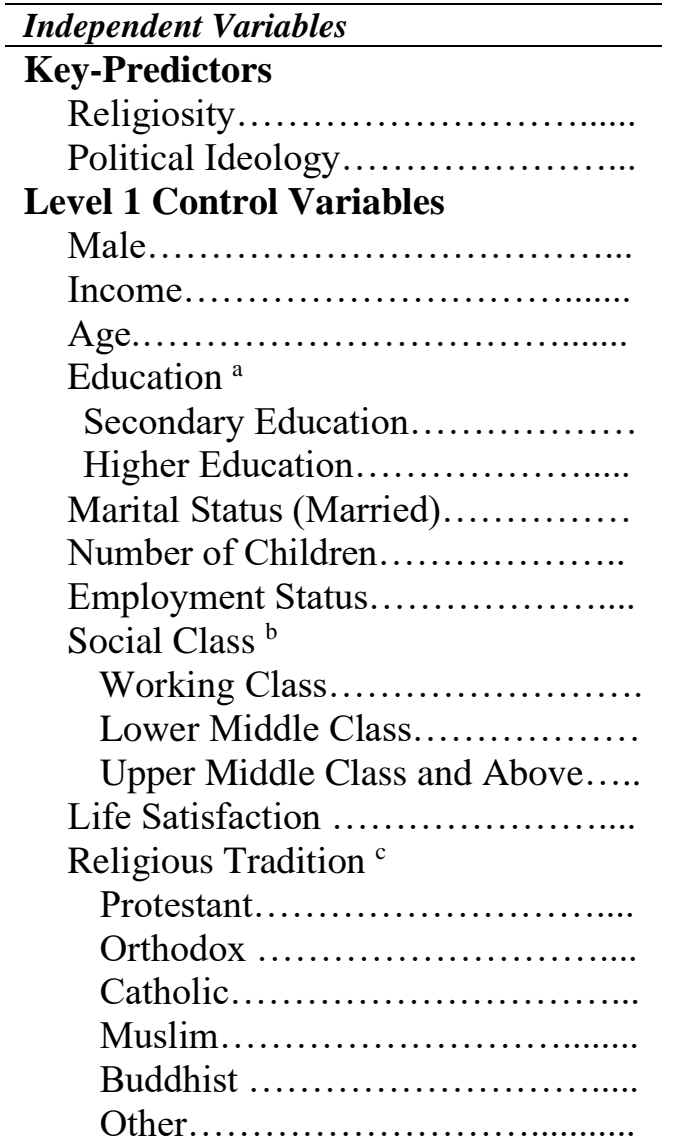

\section{Level 2 Control Variables}

GDP per capita (logged)

$\mathrm{CO}_{2}$ emissions per capita..............

Unemployment Rate..................

Democracy

\begin{tabular}{l}
$\begin{array}{c}\text { Willingness to pay } \\
\text { (WTP) for } \\
\text { environmental } \\
\text { protection }\end{array}$ \\
\hline O.R. $\quad$ S.E.
\end{tabular}

\begin{tabular}{ll}
\hline \multicolumn{1}{c}{ O.R. } & S.E. \\
\hline & \\
$1.172 * * *$ & $(.03)$ \\
0.987 & $(.02)$
\end{tabular}

1.028

1.012

0.999

$(.03)$

$(.01)$

(.00)

$1.263 * * *$

$(.05)$

$1.659 * * *$

(.09)

0.994

(.03)

$0.982 *$

(.01)

0.993

(.03)

\section{$1.189 * * * \quad(.06)$}

$1.363^{* * *} \quad(.07)$

$1.446 * * * \quad(.09)$

$1.057 * * *$

(.01)

$0.801 * *$

(.07)

$0.604 * *$

(.10)

$0.862 *$

$0.799 *$

1.180

0.834

(.12)

(.08)

$\begin{array}{ll}0.636^{* * * *} & (.07) \\ 1.001^{*} & (.00) \\ 0.956^{* * *} & (.01) \\ 1.043^{* *} & (.01)\end{array}$

Agreement with an

increase in taxes

(AIT) to prevent

environmental

pollution

\begin{tabular}{ll} 
O.R. & S.E. \\
\hline
\end{tabular}

$\begin{array}{ll}1.117 * * * & (.03) \\ 0.991 & (.02)\end{array}$

1.010

(.02)

$1.024 *$

(.01)

1.000

(.00)

$1.188 * * * \quad(.04)$

$1.373 * * * \quad(.08)$

$1.008 \quad(.03)$

$0.978 * * \quad(.01)$

1.026

(.03)

$1.107 * \quad(.06)$

$1.198 * * * \quad(.05)$

$1.235 * * \quad(.08)$

$1.056^{* * *} \quad(.01)$

$0.805 * \quad(.07)$

$0.525 * * * \quad(.06)$

$0.821 * * \quad(.06)$

$0.686 * * \quad(.08)$

$1.878 *$

$0.787 * *$

(.52)

(.06) choosing environmental protection over economic interests (CEP)

\begin{tabular}{ll}
\hline \multicolumn{1}{c}{ O.R. } & S.E. \\
\hline & \\
$1.129 * * *$ & $(.03)$ \\
0.989 & $(.02)$
\end{tabular}

1.031

$1.023 *$

$\begin{array}{ll}1.179 * * * & (.04) \\ 1.404 * * * & (.08) \\ 1.012 & (.03) \\ 0.978 * & (.01) \\ 1.002 & (.03)\end{array}$

$1.150 * * \quad(.05)$

$1.249 * * * \quad(.05)$

$1.291 * * * \quad(.07)$

$1.060 * * * \quad(.01)$

$0.780 * * \quad(.06)$

$0.548 * * * \quad(.07)$

$0.791 * * * \quad(.05)$

$0.707 * * \quad(.09)$

2.080* $\quad(.61)$

$0.802 * \quad(.07)$

$\begin{array}{llll}0.752 * * & (.08) & 0.773 * * & (.06) \\ 1.001 & (.00) & 1.000 & (.00) \\ 0.961 * * * & (.00) & 0.967 * * * & (.00) \\ 1.063 * * * & (.02) & 1.053 * * & (.02)\end{array}$

\begin{tabular}{lccc}
\hline Variance of Level 2 Intercepts (S.E.) & $0.63(0.19)$ & $0.58(0.23)$ & $0.62(0.22)$ \\
N of Countries & 43 & 43 & 43 \\
N of Observations & 44,391 & 44,391 & 44,391 \\
AIC & 52,490 & 57,534 & 58,298 \\
BIC & 52,725 & 57,769 & 58,533 \\
\hline
\end{tabular}

NOTE. - Robust standard errors in parentheses.

Data sources:

- $\quad$ Individual Level: World Value Survey longitudinal dataset (1999 - 2009)

- $\quad$ Country Level: Penn World Table 9.0 - 2015; Polity IV Project - 2015; World Development Indicators (World Bank) - 2015. Carbon

Dioxide Information Analysis Center (CDIAC) - 2011

${ }^{\text {a }}$ Reference group: Elementary or Less Education

${ }^{\mathrm{b}}$ Reference group: Lower Class

${ }^{\mathrm{c}}$ Reference group: No Religious Denomination.

$\left({ }^{\dagger} p<0.10, * p<0.05, * * p<0.01, * * * p<0.001\right)$ 
TABLE 3. MiXed-EFFECTS LOGISTIC REgRESSION MOdELS OF ENVIRONMENTAL ATTITUDES With AN INTERACTION EFFECT OF RELIGIOSITY BY POLITICAL IDEOLOGY

\begin{tabular}{|c|c|c|c|c|c|c|}
\hline Dependent Variable & \multicolumn{2}{|c|}{$\begin{array}{l}\text { Willingness to pay (WTP) } \\
\text { for environmental } \\
\text { protection }\end{array}$} & \multicolumn{2}{|c|}{$\begin{array}{c}\text { Agreement with an } \\
\text { increase in taxes (AIT) to } \\
\text { prevent environmental } \\
\text { pollution }\end{array}$} & \multicolumn{2}{|c|}{$\begin{array}{l}\text { choosing environmental } \\
\text { protection over economic } \\
\text { interests (CEP) }\end{array}$} \\
\hline & Model 1 & Model 2 & Model 3 & Model 4 & Model 5 & Model 6 \\
\hline Independent Variables & $\begin{array}{c}\text { O.R. } \\
\text { (S.E.) } \\
\end{array}$ & $\begin{array}{c}\text { O.R. } \\
\text { (S.E.) }\end{array}$ & $\begin{array}{c}\text { O.R. } \\
\text { (S.E.) }\end{array}$ & $\begin{array}{c}\text { O.R. } \\
\text { (S.E.) }\end{array}$ & $\begin{array}{c}\text { O.R. } \\
\text { (S.E.) }\end{array}$ & $\begin{array}{c}\text { O.R. } \\
\text { (S.E.) }\end{array}$ \\
\hline Main Effects & & & & & & \\
\hline Religiosity.............................. & $\begin{array}{l}1.172 * * * \\
(.03)\end{array}$ & $\begin{array}{l}0.956 \\
(.03)\end{array}$ & $\begin{array}{l}1.117 * * * \\
(.03)\end{array}$ & $\begin{array}{l}0.921^{* *} \\
(0.03)\end{array}$ & $\begin{array}{l}1.129 * * * \\
(0.03)\end{array}$ & $\begin{array}{l}0.931 * * \\
(0.03)\end{array}$ \\
\hline Political Ideology ........................ & $\begin{array}{l}0.987 \\
(.02)\end{array}$ & $\begin{array}{l}0.984 * * * \\
(.01)\end{array}$ & $\begin{array}{l}0.991 \\
(.02)\end{array}$ & $\begin{array}{l}0.987 * * \\
(0.01)\end{array}$ & $\begin{array}{r}0.989 \\
(0.02)\end{array}$ & $\begin{array}{l}0.983 * * \\
(0.01)\end{array}$ \\
\hline $\begin{array}{l}\text { Interaction Effect } \\
\quad \text { Religiosity } \times \text { Political Ideology } \ldots . \ldots \ldots \ldots\end{array}$ & & $\begin{array}{l}1.038 * * * \\
(.01)\end{array}$ & & $\begin{array}{l}1.036 * * * \\
(0.01)\end{array}$ & & $\begin{array}{l}1.037 * * * \\
(0.01)\end{array}$ \\
\hline $\begin{array}{l}\text { Level } 1 \text { control variables }{ }^{a}{ }^{b} . \ldots \ldots \ldots \ldots \ldots \\
\text { Level } 2 \text { control variables }{ }^{b} \ldots \ldots \ldots \ldots \ldots\end{array}$ & $\begin{array}{l}\text { Yes } \\
\text { Yes }\end{array}$ & $\begin{array}{l}\text { Yes } \\
\text { Yes }\end{array}$ & $\begin{array}{l}\text { Yes } \\
\text { Yes }\end{array}$ & $\begin{array}{l}\text { Yes } \\
\text { Yes }\end{array}$ & $\begin{array}{l}\text { Yes } \\
\text { Yes }\end{array}$ & $\begin{array}{l}\text { Yes } \\
\text { Yes }\end{array}$ \\
\hline $\begin{array}{l}\text { Variance of Level } 2 \text { Intercepts } \\
\text { (S.E.) } \\
\mathrm{N} \text { of Countries } \\
\mathrm{N} \text { of Observations } \\
\text { AIC } \\
\text { BIC }\end{array}$ & $\begin{array}{c}0.63 \\
(0.19) \\
43 \\
44,391 \\
52,482 \\
52,717\end{array}$ & $\begin{array}{c}0.65 \\
(0.21) \\
43 \\
44,391 \\
52,420 \\
52,663\end{array}$ & $\begin{array}{c}0.59 \\
(0.24) \\
43 \\
44,391 \\
57,536 \\
57,770\end{array}$ & $\begin{array}{c}0.59 \\
(0.15) \\
43 \\
44,391 \\
57,472 \\
57,716\end{array}$ & $\begin{array}{c}0.62 \\
(0.23) \\
43 \\
44,391 \\
58301 \\
58536\end{array}$ & $\begin{array}{c}0.35 \\
(0.08) \\
43 \\
44,391 \\
57,754 \\
57,988\end{array}$ \\
\hline
\end{tabular}

NOTE. - Robust standard errors in parentheses.

Data sources:

- $\quad$ Individual Level: World Value Survey longitudinal dataset (1999 - 2009)

- $\quad$ Country Level: Penn World Table 9.0 - 2015; Polity IV Project - 2015; World Development Indicators (World Bank) - 2015. Carbon Dioxide Information Analysis Center (CDIAC) - 2011

a Level 1 control variables include: Gender, Income, Age, Education, Marital Status, Number of Children, Employment Status, Social Class, Life Satisfaction, and Religious Tradition

${ }^{\mathrm{b}}$ Level 2 control variables include: GDP per capita, $\mathrm{CO}_{2}$ emissions per capita, Unemployment Rate, and Democracy

$(* p<0.05, * * p<0.01, * * * p<0.001)$ 
Figure 1. Predicted Probabilities of Outcome Variables by Religiosity Across Political Ideology.
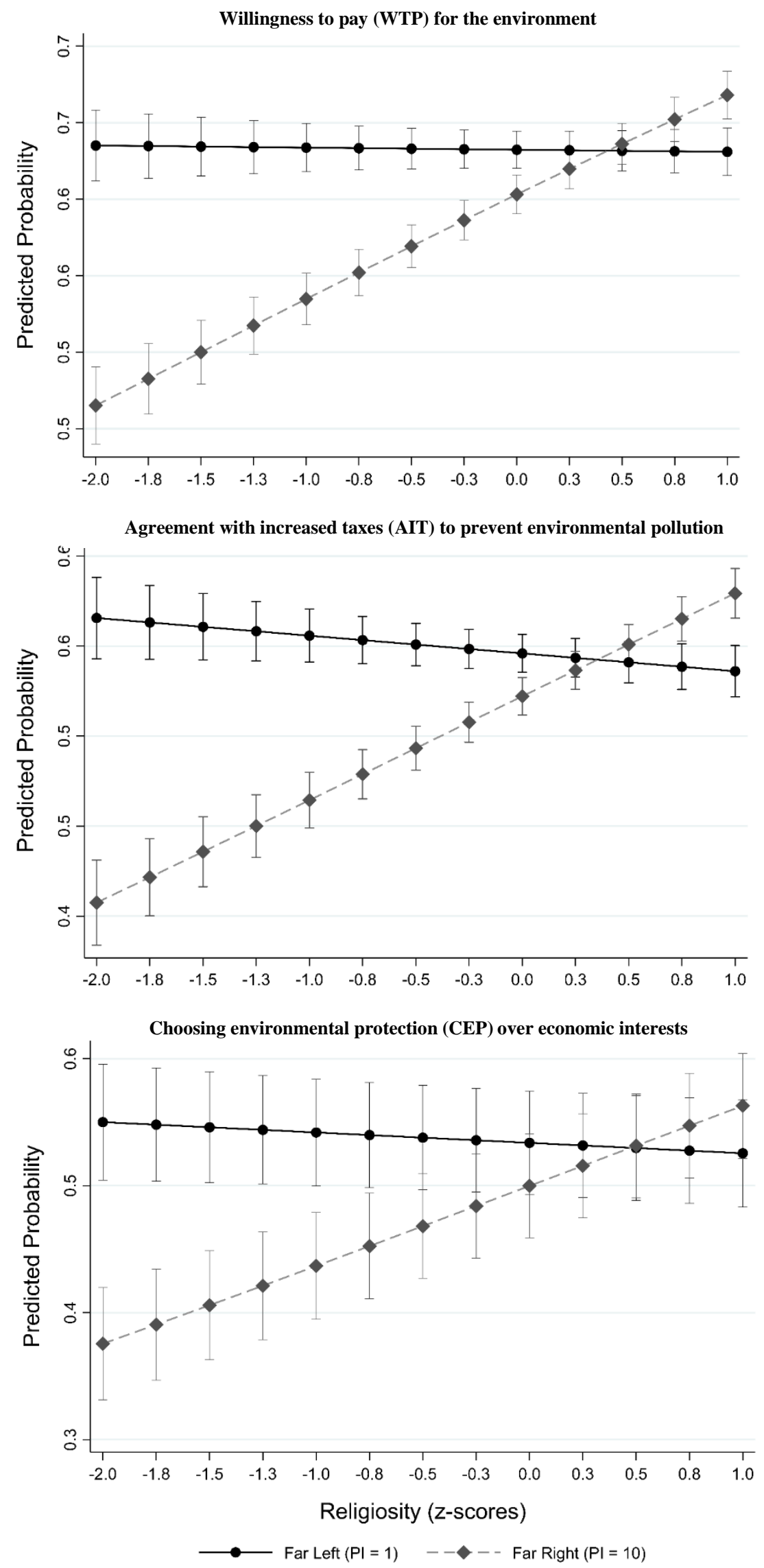

Data Source: World Values Survey (1999-2009) - N=44,391 
APPENDIX A. COUNTRIES INCLUDED IN THE SAMPLE AND THEIR

RESPECTIVE NUMBERS OF CONTRIBUTED OBSERVATIONS

\begin{tabular}{|c|c|}
\hline Countries & Number of Observations \\
\hline Albania & 764 \\
\hline Argentina & 757 \\
\hline Australia & 1,124 \\
\hline Brazil & 1,293 \\
\hline Bulgaria & 484 \\
\hline Burkina Faso & 767 \\
\hline Canada & 2,656 \\
\hline Chile & 1,490 \\
\hline Cyprus & 945 \\
\hline Egypt & 2,700 \\
\hline Finland & 768 \\
\hline Georgia & 704 \\
\hline Germany & 845 \\
\hline Hungry & 566 \\
\hline Indonesia & 1,093 \\
\hline Italy & 475 \\
\hline Japan & 1,045 \\
\hline Kyrgyzstan & 910 \\
\hline Macedonia & 743 \\
\hline Mali & 698 \\
\hline Mexico & 821 \\
\hline Moldova & 1,164 \\
\hline Morocco & 392 \\
\hline New Zealand & 385 \\
\hline Norway & 872 \\
\hline Peru & 2,135 \\
\hline Philippines & 1,099 \\
\hline Poland & 580 \\
\hline Romania & 720 \\
\hline Slovenia & 501 \\
\hline South Africa & 3,882 \\
\hline South Korea & 1,186 \\
\hline Spain & 1,499 \\
\hline Sweden & 781 \\
\hline Switzerland & 894 \\
\hline Tanzania & 635 \\
\hline Thailand & 1,447 \\
\hline Trinidad And Tobago & 601 \\
\hline Turkey & 1,013 \\
\hline Ukraine & 452 \\
\hline United States & 980 \\
\hline Uruguay & 746 \\
\hline Vietnam & 830 \\
\hline
\end{tabular}

Data source: World Values Survey (1999 - 2009) 
APPENDIX B. RELIGIOUS DENOMINATIONS

\begin{tabular}{ll}
\hline $\begin{array}{c}\text { Religious Tradition (\% in the } \\
\text { sample) }\end{array}$ & \multicolumn{1}{c}{ Religious Denominations } \\
\hline Protestant (18.0\%) & $\begin{array}{l}\text { Alliance, Anglican, Faith in God, Assembly of God, Mennonite, } \\
\text { Seven Day Adventist, The Church of Sweden, Methodist, } \\
\text { Lutheran, Church of Christ, Presbyterian, United, Aglipayan, } \\
\text { Protestant, Baptist, Charismatic, Evangelical, Born again, Jesus is } \\
\text { Lord (JIL), Pentecostal, Salvation Army, Jesus Miracle Crusade }\end{array}$ \\
Orthodox (10.0\%) & Gregorian, Orthodox, Greek Catholic \\
Catholic $(28.7 \%)$ & Roman Catholic \\
Buddhist (5.2\%) & Hoa Hao, Buddhist \\
Muslim (17.2\%) & Muslim \\
& $\begin{array}{l}\text { Ancestral worshipping, Bahai, Brgy. Sang Birhen, Cao dai, } \\
\text { Christian, El Shaddai, Filipinista, Free church/Non- } \\
\text { denominational church, Hindu, Iglesia ni Cristo (INC), }\end{array}$ \\
& $\begin{array}{l}\text { Independent African Church, Israelita Nuevo Pacto Universal } \\
\text { (FREPAP), Jain, Jehovah witnesses, Jew, Ka-a Elica, Mormon, }\end{array}$ \\
Native, New Testament Christ/Biblist, Other, Other: Brasil: \\
Espirit,candomblé,umband, Other: Christian com, Other: Oriental, \\
Paganism, Self Lealisation Fellowship, Sikh, Spiritista, \\
Spiritualists, Taoist, The Worldwide Church of God, Unitarian, \\
Zoroastrian, Ratana
\end{tabular}

